\title{
Value Domain Concept
}

National Cancer Institute

\section{Source}

National Cancer Institute. Value Domain Concept. NCI Thesaurus. Code C42749.

Concepts for a Value Domain. 